\title{
Postępy w diagnostyce i leczeniu chorych na przewlekłą białaczkę limfocytową
}

\author{
Advances in the diagnosis and treatment of patients \\ with chronic lymphocytic leukemia
}

\author{
Tadeusz Robak ${ }^{1}$, Ewa Lech-Marańda ${ }^{2,}{ }^{3}$, Krzysztof Warzocha ${ }^{2}$ \\ ${ }^{1}$ Katedra i Klinika Hematologii, Uniwersytet Medyczny, Łódź \\ ${ }^{2}$ Klinika Hematologii, Instytut Hematologii i Transfuzjologii, Warszawa \\ ${ }^{3}$ Klinika Hematologii i Transfuzjologii, Centrum Medyczne Kształcenia Podyplomowego, Warszawa
}

\begin{abstract}
Streszczenie
W ostatnich latach dokonat się istotny postęu zarówno w poznaniu biologii przewlektej białaczki limfocytowej (CLL), jak i nowych metod leczenia. Wiele badań klinicznych dostarczyto dalszych dowodów na istotna role immunochemioterapii w leczeniu I linii oraz chorych opornych na wcześniejsza terapie. W ostatnim czasie inhibitory kinaz bioracych udziat w przekazywaniu sygnatów $z$ receptora B-komórkowego zarejestrowano do leczenia opornych $i$ źle rokujacych postaci CLL. $W$ pracy przedstawiono najważniejsze osiagniecia $w$ tym zakresie $w$ ostatnich 5 latach.

Słowa kluczowe: przewlekła białaczka limfocytowa, immunochemioterapia, inhibitory BCR, inhibitory BCL2, limfocyty CAR, przeszczepienie allogenicznych krwiotwórczych komórek macierzystych
\end{abstract}

Hematologia 2015; 6, 1: 19-30

\begin{abstract}
Significant strides in understanding the biology of chronic lymphocytic leukaemia (CLL) have recently been made, thereby resulting in the development of more effective therapies. Several clinical trials support the key role that immunotherapy and targeted drugs play for managing patient treatment in those either newly diagnosed or with relapsed/refractory CLL. Furthermore, kinase inhibitors participating in B-cell receptor signalling pathways have been currently approved in treating patients suffering this condition. A summary review is hereby presented describing the most relevant achievements made within this field over the last 5 years.
\end{abstract}

Key words: chronic lymphocytic leukemia, immunochemotherapy, BCR inhibitors, BCL2 inhibitors, CAR lymphocytes, allogeneic hematopoietic stem cells transplantation

Hematologia 2015; 6, 1: 19-30

\section{Wprowadzenie}

Przewlekła białaczka limfocytowa (CLL, chronic lymphocytic leukemia) jest najczęstszym typem białaczki w Europie i Ameryce Północnej. Przebieg kliniczny choroby jest bardzo różnorodny, co wynika $z$ jej dużej heterogenności biologicznej. W ostatnich latach dokonał się istotny postęp zarówno w poznaniu biologii CLL, jak i nowych metod leczenia. Wiele badań klinicznych dostarczyło dalszych

Adres do korespondencji: Tadeusz Robak, Katedra i Klinika Hematologii, Uniwersytet Medyczny, ul. Ciołkowskiego 2, 93-510 Łódź, tel. 4268951 91, faks: 4268951 92, e-mail: robaktad@csk.umed.lodz.pl 
dowodów na istotną rolę immunochemioterapii zarówno w leczeniu I linii, jak i chorych opornych na wcześniejszą terapię. Rytuksymab w połączeniu $z$ analogami puryn i cyklofosfamidem jest obecnie standardem leczenia młodszych pacjentów bez współistniejących chorób. Na podstawie badań CLL11 i COMPLEMENT1 u starszych chorych w gorszym stanie ogólnym obecnym standardem leczenia I linii jest chlorambucyl (Chl) w połączeniu $z$ przeciwciałem anty-CD20. W ostatnim czasie inhibitory kinaz biorących udział w przekazywaniu sygnałów $z$ receptora $\mathrm{B}$-komórkowego (BCR, $B$-cell receptor) - ibrutynib i idelalisib - zarejestrowano do leczenia chorych na oporne i źle rokujące postaci CLL. Ponadto inhibitor antyapoptotycznego białka BCL2 - wenetoklaks (ABT-199) - wykazuje obiecującą aktywność w leczeniu tej białaczki. Mimo postępów w immunochemioterapii i terapii celowanej wciąż istnieje miejsce dla przeszczepiania allogenicznych krwiotwórczych komórek macierzystych (allo-HSCT, allogeneic hematopoietic stem cells transplantation). Ostatnio obiecujące wyniki uzyskano u pacjentów $z$ opornymi postaciami CLL, stosując immunoterapię limfocytami T z genetycznie modyfikowaną ekspresją receptora (CAR, chimeric antigen receptor) dla CD19. W pracy przedstawiono najważniejsze osiągnięcia w tym zakresie w ostatnich 5 latach.

\section{Wskazania do rozpoczęcia leczenia}

Uważa się, że chorzy na CLL bezobjawową $i$ bez cech progresji nie powinni być leczeni. Zasada ta wynika $z$ badań randomizowanych i metaanaliz, w których brak terapii porównywano $z$ leczeniem środkami alkilującymi [1]. Nie jest jednak jasne, czy wprowadzenie nowszych leków, w tym analogów zasad purynowych, przeciwciał monoklonalnych i ostatnio terapii celowanej, nie powinno zmienić tej strategii. W badaniu grupy niemieckiej (GCLLSG, German CLL Study Group) CLL7 porównywano leczenie za pomocą immunochemioterapii FCR (fludarabina, cyklofosfamid, rytuksymab) u źle rokujących chorych bez objawów w stadium zaawansowania Binet A bezpośrednio po rozpoznaniu CLL $z$ grupą chorych leczonych dopiero po wystąpieniu progresji [2]. Do badania kwalifikowano chorych, u których stwierdzono przynajmniej dwa $z$ czterech niekorzystnych czynników prognostycznych, $\mathrm{w}$ tym czas podwojenia limfocytów krótszy niż 12 miesięcy, aktywność kinazy tymidynowej w surowicy ponad $10 \mathrm{j}$./l, obecność niezmutowanych regionów zmiennych genu kodującego łańcuch ciężki immunoglobulin ( $I G H V$, immunoglobulin variable region heavy chain gene) i niekorzystną cytogenetykę (trisomia 12, del17p lub del11q). Stwierdzono, że wczesne rozpoczęcie leczenia za pomocą RFC wydłuża przeżycie wolne od progresji (PFS, progression-free survival), ale nie wplywa na całkowity czas przeżycia (OS, overall survival).

\section{Leczenie pierwszej linii}

Leczenie I linii ma kluczowe znaczenie dla czasu przeżycia chorych na CLL. Wybór optymalnej terapii u wcześniej nieleczonych chorych zależy od ich wieku i współistniejących chorób. W ostatnich latach przeprowadzono kilka dużych randomizowanych badań, których wyniki kształtują obecne standardy postępowania.

\section{Leczenie młodszych chorych}

$\mathrm{W}$ tej grupie pacjentów istotne znaczenie $\mathrm{w}$ leczeniu I linii mają analogi zasad purynowych, bendamustyna (BEN) i rytuksymab. Knauf i wsp. [3, 4] przedstawili wyniki badania, $\mathrm{w}$ którym porównywano skuteczność i toksyczność BEN z Chl u 319 chorych z CLL (Binet B/C, mediana wieku 64 lata). Autorzy wskazywali na znaczną aktywność BEN u chorych z CLL przy akceptowalnej toksyczności. Uzyskane łączne odsetki odpowiedzi (ORR, overall response rate) wynosiły odpowiednio $68 \%$ versus $31 \%$ $(\mathrm{p}<0,0001)$ i dla całkowitych remisji (CR) $31 \%$ versus $2 \%(\mathrm{p}<0,0001)$. W analizie intent-to-treat mediana PFS wynosiła odpowiednio 21,2 versus 8,8 miesiąca ( $\mathrm{c}<0,0001$ ), a mediana czasu do kolejnego leczenia (TTT, time to next treatment) - 31,5 versus 10,1 miesiąca $(\mathrm{p}<0,0001)$. Mediana OS nie różniła się istotnie między badanymi grupami, ale u pacjentów uzyskujących CR (prawie wyłącznie po BEN) mediana OS była dłuższa niż u pozostałych chorych (nieosiągnięta v. 76,2 miesiąca; $\mathrm{p}=0,002$ ).

Kluczowe znaczenie dla obecnych standardów leczenia I linii młodszych chorych bez współistniejących schorzeń miały wyniki badania CLL8, podjętego przez GCLLSG, German CLL Study Group we współpracy międzynarodowej $[5,6]$. W badaniu tym porównano leczenie według schematu FCR z FC (fludarabina, cyklofosfamid) w dużej grupie 817 chorych w dobrym stanie ogólnym, bez współistniejących chorób. Łączny odsetek odpowiedzi wynosił odpowiednio $95,1 \%$ i $88,4 \%$, a CR $-44,1 \%$ i $21,8 \%$. Przy medianie obserwacji 5,9 roku mediana OS w grupie chorych leczonych FCR nie została osiągnięta, a u pacjentów leczonych FC wynosiła 86 miesięcy $(\mathrm{p}=0,001)$. Neutropenię 3. i 4. stopnia według Światowej Organizacji Zdrowia (WHO, World Health Organization) obserwowano u 33,7\% 
chorych leczonych FCR i $21 \%$ chorych leczonych $\mathrm{FC}(\mathrm{p}<0,001)$. Jednak odsetek chorych $\mathrm{z}$ infekcją 3. i 4. stopnia według WHO był podobny w obu grupach. Autorzy przeanalizowali następnie wyniki odległe i częstość występowania wtórnych nowotworów u chorych poddanych randomizacji [7]. Zaobserwowano, że średni czas do wystąpienia nowotworu wynosił 2,4 roku od zakończenia leczenia indukującego, przy czym nie było różnic w częstości występowania wtórnych nowotworów w grupie leczonej FCR w porównaniu $z$ leczonymi FC $(9,9 \%$ v. $12,1 \% ; \mathrm{p}=0,4)$. Częstość występowania nowotworów litych określono na 5,7\%, zespołu Richtera - na 4,1\%, a zespolu mielodysplastycznego (MDS, myelodysplastic syndrome) lub ostrej białaczki szpikowej (AML, acute myeloid leukemia) - na 1,5\%. Późne neutropenie (2 miesiące po zakończeniu leczenia) 3. lub 4. stopnia według WHO występowały głównie w okresie roku po zakończeniu leczenia, statystycznie częściej u chorych leczonych FCR w porównaniu z leczonymi FC $(16,6 \% v .8,8 \%$; $\mathrm{p}=0,007)$. Nie obserwowano jednak większej częstości MDS lub AML w grupie leczonej według protokołu FCR. Grupa badaczy niemieckich analizowała równie $\dot{z}$ wpływ mutacji w genach TP53, NOTCH1, SF3B1 na odległe wyniki leczenia u 573 chorych z badania CLL8. Częstość występowania wyżej wymienionych mutacji była następująca: TP53 - 11,5\%, NOTCH1 - 10\%, SF3B1 - 18,4\%. W analizie wielowariancyjnej wykazano, że spośród analizowanych mutacji tylko obecność del(17p) i mutacji TP53 zachowywała niezależne znaczenie rokownicze $\mathrm{w}$ odniesieniu do OS. $Z$ kolei analiza jednowariancyjna dla PFS, uwzględniająca rodzaj mutacji i stosowanej chemioterapii, dowiodła, że dodanie rytuksymabu nie przynosi korzyści tylko u chorych z mutacją NOTCH1. W pozostałych podgrupach (obecność lub brak mutacji TP53, obecność lub brak mutacji $S F 3 B 1$, brak mutacji NOTCH1) obserwowano istotne statystycznie wydłużenie PFS $\mathrm{u}$ chorych leczonych FRC w porównaniu z pacjentami leczonymi FC.

Na Konferencji ASH (American Society of Hematology) w 2013 i 2014 roku przedstawiono wyniki badania CLL10, w którym porównywano FCR $z$ BEN i rytuksymabem (BR), u pacjentów bez współistniejących chorób, w tym również u starszych chorych. Wykazano większą skuteczność schematu FCR w porównaniu z BR [8, 9]. Zaobserwowano, że ORR w obu grupach wynosił po $97,8 \%$, a CR odpowiednio - 47,4\% i 38,1\% ( $\mathrm{p}=0,031)$. Szacowane 2-letnie PFS wynosiło $85 \%$ u chorych leczonych RFC i $78,2 \%$ u pacjentów otrzymujących BR $(p=0,037)$. Mediana PFS wynosiła odpowied- nio 55,2 i 41,7 miesiąca, ale różnice PFS traciły jednak znamienność statystyczną u chorych powyżej 65. roku życia. Nie obserwowano istotnych różnic w zakresie OS. Leczenie według schematu BR było mniej toksyczne niż FCR. Ciężkie objawy niepożądane, w tym neutropenia i infekcje, występowały częściej u chorych leczonych FCR (odpowiednio $81 \%$ i $39 \%$ ) niż BR (odpowiednio 39\% i 25\%). Remi i wsp. [10] przedstawiali wyniki randomizowanego badania 3. fazy francuskiej grupy badawczej GOELAMS (Groupe Ouest-Est D'etudes Des Leucémies Aigües Et Autres Maladies Du Sang), w którym porównywano schemat FCR z FCA (fludarabina, cyklofosfamid, alemtuzumab) u 178 chorych poniżej 65. roku życia. Badane grupy były jednorodne pod względem wieku, stanu zaawansowania choroby, aberracji cytogenetycznych i stanu mutacji $I G H V$. W obu grupach podano 6 cykli leczenia, odpowiednio $76,5 \%$ i 71,4\% chorym. Najczęstszą przyczyną jego przerwania była przedłużająca się neutropenia (74,6\% v. 79,6\%), której odsetek narastał w miarę leczenia po FCA i pozostawał na tym samym poziomie po FCR. Randomizację przerwano po zrekrutowaniu 165 chorych $z$ powodu toksyczności obserwowanej w grupie otrzymującej FCA. Uzyskane odsetki odpowiedzi, w tym ORR (91\% v. 85\%), CR (70\% v. 59\%) i CR bez minimalnej choroby resztkowej (MRD, minimal residual disease) (40\% v. 15\%), nie wskazywały na przewagę skuteczności FCA nad FCR.

Na Konferencji ASH w 2013 roku przedstawiono wstępne wyniki badania CLL4 Polskiej Grupy ds. Leczenia Białaczek u Dorosłych (PALG, Polish Adult Leukemia Group), w którym oceniano skuteczność immunochemioterapii RCC (rytuksymab, kladrybina, cyklofosfamid) w I linii leczenia. Po uzyskaniu odpowiedzi chorych poddano randomizacji do grupy otrzymującej terapię podtrzymującą rytuksymabem lub grupy kontrolnej [11]. Wykazano, że ORR wynosił $74 \%$ po RCC, w tym CR $22 \%$ i odpowiedź częściową (PR, partial remission) $52 \%$. Odsetek infekcji 3. lub 4. stopnia według WHO $\mathrm{w}$ obu grupach nie różnił się istotnie.

\section{Leczenie chorych w podeszłym wieku ze wspólistniejącymi chorobami}

Wielu chorych na CLL jest w podeszłym wieku i obciążonych wieloma innymi chorobami. Dlatego stosowanie przeznaczonych dla nich schematów chemioterapii opartych na fludarabinie może się wiązać $z$ dużą toksycznością. W dwóch randomizowanych badaniach wykazano, że u takich chorych lepsze wyniki uzyskuje się po dodaniu do Chl przeciwciała anty-CD20, tj. rytuksymabu, obinutuzumabu lub ofatumumabu. Na Konferencji ASH 
w 2013 roku, na sesji plenarnej, dr Valentin Goede $z$ Kolonii $\mathrm{w}$ imieniu GCLLSG przedstawił wyniki randomizowanego badania CLL11, w którym porównywano dwa protokoły immunochemioterapii z monoterapią Chl u wcześniej nieleczonych pacjentów ze wspólistniejącymi innymi chorobami, niekwalifikujących się do leczenia immunochemioterapią $z$ analogami puryn [12]. Wykazano, że immunochemioterapia $z$ zastosowaniem obinutuzumabu (GA-101) w połączeniu z Chl umożliwiła uzyskanie większych odsetków ORR i CR oraz większego odsetka pacjentów z ujemną MRD i dłuższego PFS w porównaniu $z$ chorymi leczonymi Chl skojarzonym $z$ rytuksymabem (R-Chl) lub samym Chl. Schemat R-Chl był z kolei bardziej skuteczny od monoterapii Chl. Jednak schemat GA-101+ Chl był bardziej toksyczny od dwóch pozostałych metod leczenia, zwłaszcza w zakresie reakcji związanej $z$ infuzją przeciwciała i częstości występowania neutropenii 3. lub 4. stopnia według WHO. Wyniki tego badania opublikowano później w „New England Journal of Medicine” [13].

W badaniu COMPLEMENT-1 porównano ludzkie przeciwciało monoklonalne anty-CD20 - ofatumumab, stosowane łącznie $z \mathrm{Chl}(\mathrm{O}-\mathrm{Chl})$ oraz samym Chl, u wcześniej nieleczonych chorych na CLL w podeszłym wieku i/lub ze wspólistniejącymi chorobami [14]. Podobnie jak w badaniu CLL11, chorzy leczeni immunochemioterapią O-Ch uzyskali lepsze wyniki niż pacjenci poddani monoterapii Chl w zakresie PFS, ORR, odsetka CR i odsetka chorych $z$ ujemną MRD.

Celem randomizowanego, wieloośrodkowego badania fazy $3 \mathrm{~b}$ (MaBLe) było porównanie skuteczności i bezpieczeństwa dwóch schematów leczenia — BR i R-Chl [15]. Do badania zakwalifikowano 358 chorych do leczenia I lub II linii, u których występowały przeciwwskazania do chemioterapii $\mathrm{z}$ zastosowaniem fludarabiny. Autorzy podkreślają, że badana grupa była bardzo zbliżona do populacji chorych $z$ codziennej praktyki klinicznej, gdyż mediana wieku wszystkich pacjentów wynosiła 74 lata (75 lat dla BR i 73 lata dla R-Chl) i u ponad 95\% chorych były obecne choroby towarzyszące. W obu grupach obserwowano podobne, wysokie odsetki ORR $(87,9 \%$ v. 80,9\%), ale w grupie leczonej BR odnotowano wyższy odsetek CR niż u chorych leczonych R-Chl $(24,1 \%$ v. 10,3\%; $\mathrm{p}=0,033)$. Bezpieczeństwo leczenia było podobne w obu grupach.

\section{Leczenie chorych opornych i w nawrocie}

Mimo istotnego postępu w leczeniu chorych na CLL u większości dochodzi do nawrotu choroby.
Zgodnie z zaleceniami ESMO (European Society for Medical Oncology) powtarzanie I linii terapii rekomenduje się tylko u tych chorych, u których dochodzi do nawrotu po czasie dłuższym niż 24 miesiące od zakończenia leczenia indukującego [16]. Nie wiadomo jednak, jaki schemat leczenia wybrać dla chorego we wczesnym nawrocie lub $z$ oporną CLL. W tym zakresie na uwagę zasługują wyniki metaanalizy 1558 chorych leczonych w 5 prospektywnych badaniach klinicznych (CLL4, CLL5, CLL8, CLL2L, CLL2M) grupy GCLLSG [17]. Leczenia II linii wymagało $704(45,2 \%)$ chorych, u których zastosowano różne schematy immuno- i/lub chemioterapii: FC (11\%), BR (11\%), fludarabinę (9\%), $\mathrm{BEN} \pm$ steroidy (9\%), R-CHOP (rytuksymab, cyklofosfamid, adriblastyna, winkrytyna, prednizon) (8\%), $\mathrm{Chl} \pm$ steroidy (8\%), FCR (8\%), alemtuzumab \pm steroidy (6\%), inne (5\%). Zaobserwowano, że leczenie oparte na schematach zawierających przeciwciała monoklonalne (MoAbs, monoclonal antibodies) wydłuża 5-letnie OS w porównaniu ze schematami bez MoAbs (76\% v. 64\%; $\mathrm{p}<0,001)$, ale nie jest istotne, do której linii leczenia je dodano ( 1 linia $v . \geq 2$ linie). Spośród chorych wymagających leczenia II linii 315 (20\%) otrzymało to leczenie w czasie krótszym niż 24 miesiące od zakończenia leczenia I linii. Chorych podzielono na trzy grupy: grupa 1 . otrzymywała MoAbs $\pm 1-2$ cytostatyki, grupa 2 . była leczona monoterapią bez MoAbs, zaś w grupie 3. stosowano 3 lub więcej cytostatyków \pm antracykliny. Zaobserwowano, że najdłuższe przeżycie wolne od leczenia (TFS, treatment-free survival) cechowało chorych z grupy 1. w porównaniu $z$ grupami 2 . i 3. $(24,5$ v. 18,7 v. 16,4 miesiąca; $\mathrm{p}=0,009$ ); podobnie przedstawiało się OS: 78,3 v. 58,2v. 42 miesiące ( $\mathrm{p}=0,012)$, odpowiednio w grupach 1., 2.i3. Autorzy uważają, że $\mathrm{u}$ chorych $\mathrm{z}$ wczesnym nawrotem standardowa immunochemioterapia czy alemtuzumab w monoterapii są bardziej skuteczne niż polichemioterapia oparta na 3 lub większej liczbie cytostatyków \pm antracykliny. U chorych $z$ nawrotem/opornością schemat BR może być skuteczny nawet u pacjentów $z$ grupy wysokiego ryzyka. Schemat alemtuzumab z deksametazonem prowadził do uzyskania wysokiego odsetka ORR/CR $\mathrm{u}$ chorych $\mathrm{w}$ grupie leczonych fludarabiną. Jednak obecnie u chorych opornych na immunochemioterapię lepsze wyniki można uzyskać, stosując inhibitory przekazywania sygnału z BCR - ibrutynib lub idelalisib.

\section{Leczenie podtrzymujące i konsolidujące}

U chorych na chłoniaka grudkowego i starszych pacjentów $z$ chłoniakiem $z$ komórek płaszcza 
leczenie podtrzymujące rytuksymabem ma ustaloną wartość i należy do standardów postępowania. Jednak w CLL leczenie podtrzymujące nie ma ustalonej wartości [18]. W ostatnich latach pojawity się doniesienia oceniające leczenie podtrzymujące rytuksymabem, ofatumumabem i lenalidomidem u chorych na CLL. Egle i wsp. [19] przedstawili końcowe wyniki badania $z$ zastosowaniem leczenia podtrzymującego rytuksymabem u wcześniej nieleczonych 43 chorych $z$ CLL (mediana wieku 60 lat), otrzymujących w indukcji schemat FCR i FR (fludarabina, rytuksymab). W badaniu tym po 3 cyklach FCR i 3 cyklach FR zastosowano rytuksymab w dawce podtrzymującej $375 \mathrm{mg} / \mathrm{m}^{2}$ co 3 miesiące przez 2 lata. W wyniku indukcji uzyskano $69 \%$ CR, 21\% PR i 9\% stabilizacji choroby ( $\mathrm{SD}$, stable disease), ale 10 chorych nie poddano ocenie, w tym $4 \mathrm{z}$ powodu sepsy, 1 ze względu na nietolerancję rytuksymabu, $2 \mathrm{z}$ powodu hemolizy i 3 z powodu działań niepożądanych niezwiązanych $z$ leczeniem. Po zakończeniu leczenia indukującego $31(72 \%)$ chorych otrzymało co najmniej 1 dawkę rytuksymabu w podtrzymywaniu, spośród których 74\% ukończyło 8 cykli leczenia podtrzymującego. Przyczynami przerwania leczenia podtrzymującego były infekcje (13\%), leukopenia (3\%), progresja choroby (3\%) i odmowa chorego (6\%). W wyniku leczenia podtrzymującego u 5 spośród 31 chorych (16\%) osiągnięto poprawę stanu remisji po indukcji, a u dodatkowych 7 chorych normalizacji uległy parametry krwi obwodowej (cytopenie). Autorzy doniesienia wskazują na użyteczność leczenia podtrzymującego rytuksymabem u chorych na CLL, choć jednocześnie wskazują na stosunkowo niski odsetek pacjentów, u których takie leczenie można rozpocząć i zakończyć zgodnie $z$ wcześniej przyjętym protokołem.

Garcia-Marco i wsp. [20] przedstawili wyniki analizy etapowej leczenia podtrzymującego rytuksymabem $\left(375 \mathrm{mg} / \mathrm{m}^{2}\right.$ co 2 miesiące przez 3 lata) chorych na CLL, uzyskujących odpowiedź kliniczną po wcześniejszej indukcji według programu FCR. Do badania zakwalifikowano 84 chorych $z$ medianą wieku 59,5 roku. Wykazano obecność CR bez MRD (MRD[-]) u 57\% chorych, CR z MRD (MRD[+]) u $21,5 \%$, PR MRD(-) u 7,6\% i PR MRD(+) u 13,9\% chorych. Spośród 75 chorych, którzy ukończyli indukcję, 70 otrzymało rytuksymab, w tym 37 (49,3\%) ukończyło pełny rok leczenia podtrzymującego (6 cykli). U tych chorych odnotowano zwiększenie odsetka CR MRD(-) z 70,2\% do $97,3 \%$. Do najczęstszych działań niepożądanych w stopniu 3. lub 4. według WHO należały neutropenia między cyklami $(16,7 \%)$ oraz infekcje $(41,7 \%)$.
W 2010 roku Bosch i wsp. [21] przedstawili wstępne wyniki badania, w którym leczenie indukujące prowadzono według protokołu R-FCM (rytuksymab, fludarabina, cyklofosfamid, mitoksantron), a u 67 chorych, którzy uzyskali CR lub $\mathrm{PR}$, stosowano leczenie podtrzymujące rytuksymabem w dawce $375 \mathrm{mg} / \mathrm{m}^{2}$ co 3 miesiące przez 2 lata. W 2013 roku opublikowano wyniki końcowej analizy, w której wykazano, że po zakończeniu leczenia podtrzymującego $40,6 \%$ chorych uzyskało CR MRD(-), 40,6\% miało CR MRD(+), 4,8\% pozostawało w PR, a u $14 \%$ stwierdzono progresję [22]. Sześciu z 29 (21\%) chorych, którzy byli w CR $\mathrm{MRD}(+)$ lub w PR po R-FCM, uzyskało poprawę po zastosowaniu leczenia podtrzymującego rytuksymabem. Czteroletnie PFS osiagnęło 74,8\% chorych, a 4-letnie OS - 93,7\% chorych. Obserwowana toksyczność dotyczyła przede wszystkim neutropenii $(31,8 \%)$, małopłytkowości $(3,4 \%)$, niedokrwistości (3,9\%), hipogammaglobulinemii (38\%) oraz infekcji i reaktywacji zakażeń Herpes-Zoster.

Shanafelt i wsp. [23] przedstawili wyniki leczenia konsolidującego za pomocą lenalidomi$\mathrm{du}$ (w dawce początkowej $5 \mathrm{mg} / \mathrm{d}$., a następnie $10 \mathrm{mg} / \mathrm{d}$. przez 6 miesięcy) po 6 cyklach leczenia indukującego według protokołu PCR (pentostatyna, cyklofosfamid, rytuksymab). Z 44 zakwalifikowanych do badania chorych 38 (86\%) ukończyło 6 zaplanowanych wcześniej cykli według schematu PCR. W wyniku leczenia indukującego ORR wyniosło $98 \%$, w tym 18 chorych uzyskało CR, w tym $4-\mathrm{MRD}(-)$, a 25 pacjentów - PR. Spośród tych chorych 34 otrzymało konsolidację lenalidomidem, po której obserwowano hematologiczne działania niepożądane w stopniu 3. lub 4. u 22 (65\%) chorych i pozahematologiczne u 4 (12\%). Po medianie czasu obserwacji wynoszącej 16 miesięcy 42 spośród 44 pacjentów żyje, a mediana czasu trwania odpowiedzi nie została osiągnięta. Tylko u 3 (7\%) spośród tych chorych odnotowano progresję choroby. Wyniki te wskazują, że zastosowanie w konsolidacji lenalidomidu poprawia jakość odpowiedzi i wydłuża PFS u chorych na CLL.

W badaniu PROLONG oceniano skuteczność ofatumumabu w podtrzymywaniu remisji u chorych na CLL [24]. Mediana PFS u chorych leczonych ofatumumabem wynosiła 29,4 miesiąca, a u otrzymujących placebo - 15,2 miesiąca. Dotychczas nie wykazano jednak różnic w zakresie OS.

W innych badaniach analizowano skuteczność leczenia podtrzymującego lenalidomidem, który jest aktywny w monoterapii u chorych na CLL. $\mathrm{W}$ jednym $z$ nich u chorych $z$ nawrotem lub opornością CLL/SLL (small lymphocytic lymphoma) 
leczonych według schematu BR po uzyskaniu odpowiedzi stosowano lenalidomid [25]. Chorym podawano 6 cykli BR (BEN $90 \mathrm{mg} / \mathrm{m}^{2}$ 1. i 2 . dnia, rytuksymab $375 \mathrm{mg} / \mathrm{m}^{2} 1$. dnia). Chorzy, którzy uzyskali CR, PR lub minimalną odpowiedź, otrzymywali następnie lenalidomid w dawce $5 \mathrm{mg} /$ dobę (możliwe zwiększenie dawki do $10 \mathrm{mg} / \mathrm{d}$.) w 28-dniowych cyklach, do maksymalnie 12 cykli. Uzyskany ORR wynosił $65 \%$ (CR 18\%, PR 47\%), a mediana PFS $-24,3$ miesiąca. Zaobserwowano ponadto, że nie było różnic w ORR w całej grupie w porównaniu $z$ chorymi $z$ niekorzystnymi anomaliami cytogenetycznymi (65\% v. 55\%). Nie wykazano także różnic w odniesieniu do PFS czy OS zależnie od obecności lub braku del(11q) lub del(17p). Wyniki tego badania wskazują, że obserwowana poprawa mediany PFS w porównaniu $z$ grupami historycznymi, może wynikać $z$ korzyści z zastosowania lenalidomidu w leczeniu podtrzymującym. Na Konferencji ASH w 2014 roku również grupa niemiecka przedstawiła wstępne wyniki leczenia podtrzymującego lenalidomidem, stwierdzając dobrą tolerancję takiego postępowania [26]. Jednak wyniki skuteczności takiego postępowania nie są jeszcze dostępne.

Varghese i wsp. [27] przedstawili wyniki leczenia konsolidującego za pomocą alemtuzumabu (w dawce $30 \mathrm{mg}$ podskórnie, 3 razy w tygodniu przez 6 tygodni) u 47 chorych (mediana wieku 58 lat), które rozpoczynano 6-24 miesięcy po zakończeniu leczenia indukującego opartego na schematach zawierających fludarabinę (1-3 linii leczenia). U chorych, u których uzyskano MRD(-) albo nie odpowiedzieli na leczenie, konsolidację przerywano po 6 tygodniach, a u pozostałych kontynuowano ją przez kolejnych 6 tygodni. Podawanie alemtuzumabu przerwano u 6 chorych przed ukończeniem 6 tygodni leczenia (głównie $z$ powodu toksyczności), 32 pacjentów otrzymywało go przez 6-8 tygodni i tylko 9 chorych poddano zaplanowanemu wcześniej 12-tygodniowemu leczeniu. Po zakończeniu konsolidacji alemtuzumabem 13 spośród 23 (56\%) chorych z PR uzyskało CR, 7 (15\%) pozostało z $\mathrm{MRD}(+)$, a 39 spośród 47 (83\%) uzyskało MRD(-) w szpiku. Po 6 miesiącach od zakończenia konsolidacji 16 spośród 39 (41\%) chorych uzyskało MRD(-). Autorzy podkreślają, że konsolidacja za pomocą alemtuzumabu, chociaż wiązała się $z$ dużym ryzykiem wystąpienia działań niepożądanych, przynosiła korzyść u właściwie monitorowanych chorych.

\section{Nowe leki}

Spośród nowych leków o zatwierdzonej lub potencjalnej użyteczności u chorych na CLL naj- większe znaczenie mają inhibitory przekazywania sygnału $z \mathrm{BCR}$, inhibitory antyapoptotycznego białka BCL2 i nowe przeciwciała monoklonalne.

\section{Inhibitory BCR}

W ostatnich kilku latach wykazano, że aktywacja BCR odgrywa kluczową rolę w patogenezie i progresji CLL. Sygnał przekazywany z BCR aktywuje szereg kinaz tyrozynowych, takich jak kinazy LYN, SYK (spleen tyrosine kinase), kinaza 3-fosfatydyloinozytolu (PI3K, phosphatidylinositol 3-kinase) i kinaza Brutona (BTK, Bruton tyrosine kinase) promujących wzrost, proliferację, dojrzewanie oraz przeżycie limfocytów B [28]; FDA (Food and Drug Administration) i EMA (European Medicine Agency) zatwierdziły dwa leki z tej grupy — ibrutynib i idelalisib. Po raz pierwszy określenie patomechanizmu CLL wykorzystano praktycznie i grupa leków hamujących przekazywanie sygnału z BCR stała się nową opcją terapeutyczną.

Rejestrację ibrutynibu (PCI-32765) udokumentowano wynikami dwóch badań przedstawianych na konferencjach ASH i opublikowanych w „New England Journal of Medicine" [29]. Ważnym doniesieniem były wyniki badania fazy $1 \mathrm{~b} / 2 \mathrm{z}$ zastosowaniem ibrutynibu w monoterapii u 116 chorych nieleczonych oraz z nawrotem/opornością [30]. Pacjentów podzielono na trzy grupy: 1) nieleczonych w wieku 65 lat i starszych, 2) z nawrotem lub opornością oraz 3) wysokiego ryzyka (del[17p]) lub z nawrotem w czasie krótszym niż 24 miesiące po immunochemioterapii I linii. Ibrutynib stosowano doustnie w dawce $420 \mathrm{mg}$ /dobę lub $840 \mathrm{mg}$ /dobę; uzyskiwane ORR były wysokie u chorych nieleczonych i nie różniły się statystycznie od uzyskanych u chorych $z$ nawrotem/opornością lub $z$ grupy wysokiego ryzyka (wynosiły odpowiednio 68\% i 71\%). Szacowane 26-miesięczne PFS osiągnęło $96 \%$ chorych nieleczonych w wieku co najmniej 65 lat i $75 \%$ chorych $z$ nawrotem/opornością lub $z$ grupy wysokiego ryzyka. Różnica ta była istotna statystycznie $(\mathrm{p}=0,026)$. Należy podkreślić, że $\mathrm{w}$ grupie chorych $\mathrm{z}$ nawrotem/opornością $\mathrm{z}$ delecją lub bez delecji $17 \mathrm{p}$ nie osiągnięto mediany PFS w 22. miesiącu obserwacji; podobne były wyniki dotyczące OS. Szacowane 26-miesięczne OS osiągnęło $96 \%$ chorych nieleczonych w wieku co najmniej 65 lat i 83\% chorych $z$ nawrotem/opornością lub z grupy wysokiego ryzyka. Różnica ta była na granicy istotności statystycznej $(\mathrm{p}=0,09)$.

W przypadku stosowania inhibitorów BCR obserwuje się charakterystyczne zjawisko tak zwanej redystrybucji limfocytów, polegające na przemijającym wzroście limfocytozy w pierw- 
szych tygodniach leczenia przy jednoczesnym zmniejszaniu się wymiarów węzłów chłonnych i śledziony. Limfocytoza może nawet 5-krotnie przekroczyć wartość wyjściową, ale zwykle ustępuje po kilku miesiącach leczenia. W badaniu tym zaobserwowano, że przemijająca limfocytoza indukowana lekiem ustępowała szybciej (mediana $6,2 v .14,8$ miesiąca) i częściej $(86 \%$ v. 55\%) $\mathrm{u}$ chorych $\mathrm{z}$ niezmutowanym $I G H V \mathrm{w}$ porównaniu $z$ pacjentami ze zmutowanym $I G H V$. Obserwowane objawy niepożądane były głównie poniżej 2 . stopnia według WHO i obejmowały: biegunkę (54\%), zmęczenie (29\%), infekcje górnych dróg oddechowych (29\%), wysypkę (28\%), nudności (26\%) i bóle stawów (25\%). W pełnej publikacji przedstawiono wyniki leczenia ibrutynibem u 85 chorych ze źle rokującą, oporną lub nawrotową CLL. Wykazały one znaczną skuteczność i dobrą tolerancję leku [30]. Po 26 miesiącach obserwacji PFS osiągnęło $75 \%$ chorych, a OS - 85\%. Na uwagę zasługuje fakt, że na odsetek odpowiedzi nie wpływały liczba wcześniejszych terapii, stopień zaawansowania choroby ani obecność delecji 17p [29].

W kolejnym badaniu 2 . fazy stosowano ibrutynib w dawce $420 \mathrm{mg} /$ dobę $\mathrm{w}$ skojarzeniu $\mathrm{z}$ rytuksymabem w dawce $375 \mathrm{mg} / \mathrm{m}^{2}$ 1., 8., 15. i 22. dnia cyklu oraz 1. dnia w cyklach 2.-6. [31]. Do badania włączono 40 chorych na CLL wysokiego ryzyka (del[17p] lub mutacje TP53) z PFS krótszym niż 36 miesięcy po FCR lub nawrotem CLL $z$ obecnością del(11q); ORR wyniósł 83\%, a przy 4-miesięcznej medianie obserwacji 37 na 40 chorych kontynuowało leczenie bez progresji choroby. Leczenie było dobrze tolerowane; objawy niepożądane 3. lub 4. stopnia według WHO obserwowano u 13 chorych (neutropenia, zmęczenie, zapalenie płuc, bezsenność, bóle kości) i w większości przypadków nie były związane ze stosowanym leczeniem. Przemijający wzrost limfocytozy występował wcześniej i trwał krócej niż w przypadku monoterapii ibrutynibem.

W kolejnym badaniu 3 . fazy porównano ibrutynib $z$ ofatumumabem u 391 pacjentów z oporną lub nawrotową CLL. Wynik również był korzystny dla ibrutynibu [32-34]. U chorych leczonych ibrutynibem PFS i OS były dłuższe niż u chorych leczonych ofatumumabem, niezależnie od wcześniejszej oporności na fludarabinę i obecność delecji $17 \mathrm{p}$. W innych badaniach również potwierdzono dużą skuteczność ibrutynibu u chorych $z$ del17p lub/i mutacjami TP53. Badania przedstawione przez Farooqui i wsp. [35] wskazują, że ibrutynib jest równie skuteczny u chorych $z$ del17p jak u chorych bez tej aberracji.
Na Konferencji ASH w 2014 roku przedstawiono wyniki badań 2 . fazy skojarzonego leczenia ibrutynibem i rytuksymabem [36]. Wykazano, że terapia ta jest dobrze tolerowana i może zmniejszać stopień limfocytozy we wstępnej fazie leczenia $\mathrm{w}$ porównaniu $\mathrm{z}$ samym ibrutynibem, a w konsekwencji zwiększać odsetek CR. W badaniu 1. fazy skojarzonego leczenia ibrutynibem, rytuksymabem i BEN wykazano również dobrą tolerancję i znaczną skuteczność takiego schematu u chorych $z$ oporną lub nawrotową CLL [78]. Badacze z MD Anderson Cancer Center wykazali, że u chorych na CLL leczonych ibrutynibem złożony kariotyp jest bardziej obciążającym czynnikiem rokowniczym niż izolowana del17p lub/i mutacje TP53 [38].

Idelalisib (GS-1101, CAL-101, ZYDELIG ${ }^{\circledR}$ ) jest inhibitorem PI3K $\delta$; jego skuteczność w leczeniu chorych na CLL jest podobna do skuteczności ibrutynibu. $\mathrm{W}$ badaniu rejestracyjnym idelalisib stosowano łącznie $z$ rytuksymabem i porównano z monoterapią tym przeciwciałem u 220 chorych z nawrotową CLL [39-41]. Po 12 miesiącach OS wynosiło odpowiednio $92 \%$ i $80 \%$; badanie przerwano przed zaplanowanym terminem zakończenia po wykazaniu przewagi idelalisibu $\mathrm{z}$ rytuksymabem nad monoterapią rytuksymabem. Przeprowadzone analizy wykazały, że idelalisib cechuje znaczna aktywność terapeutyczna niezależnie od rozpatrywanych czynników rokowniczych [40]. Znaczną aktywność wykazało również połączenie idelalisibu z BEN i rytuksymabem [42]. Ponadto przedstawiono wstępne wyniki badania 1 . fazy dotyczącego idelalisibu $\mathrm{w}$ skojarzeniu $\mathrm{z}$ rytuksymabem lub ofatumumabem $u$ chorych $z$ oporną lub nawrotową CLL, podkreślając znaczną skuteczność i akceptowalną toksyczność tego typu leczenia [43].

Obecnie prowadzone są badania nad nowymi inhibitorami kinaz, w tym nad nowym inhibitorem BTK (ONO-4059) oraz nowym inhibitorem PI3K $\delta / \gamma$ - duwelisibem (IPI-145) [44-46]. Jednak ocena ich potencjalnej przewagi nad obecnie zarejestrowanym ibrutynibem i idelalisibem nie jest jeszcze możliwa.

\section{Inhibitory BCL2}

W CLL występuje nasilona ekspresja antyapoptotycznego białka BCL2, a jego inhibitory wykazują znaczną aktywność terapeutyczną w tej białaczce i stanowią kolejną obiecującą grupę leków. Obecnie największe nadzieje wiąże się ze stosowanym doustnie wenetoklaksem (GDC-0199, ABT-199) [47]. Wykazuje on znaczną aktywność u chorych na oporną i nawrotową CLL, w tym również u chorych $z$ del17p. W porównaniu $z$ innymi inhibitorami 
BCL2 wenetoklaks nie wywołuje małopłytkowości. Dotychczas przedstawiono wyniki 1 . fazy badania tego leku u chorych na oporną i nawrotową CLL [48]. Odpowiedź uzyskano u $84 \%$ chorych, w tym CR u $20 \%$. Na uwagę zasługuje fakt, że odsetek $\mathrm{CR}$ w podobnych grupach chorych jest znacznie większy po leczeniu ABT-199 niż inhibitorami BCR. Podobne wyniki stwierdzono u chorych $z$ del17p (ORR 82\%) oraz u opornych na fludarabinę (ORR 78\%). W badaniach przedklinicznych ABT-199 wykazywał synergizm $z$ przeciwciałami anty-CD20, co uzasadniało rozpoczęcie badań klinicznych nad łącznym stosowaniem tych leków u chorych na CLL. Roberts i wsp. [49] przedstawili wstępne wyniki badania u chorych na oporną i nawrotową CLL leczonych ABT-199 i rytuksymabem. Spośród 49 chorych zakwalifikowanych do badań u 13 przerwano leczenie $z$ powodu uzyskania $C R$ $(n=3)$, progresji $(n=6)$, toksyczności $(n=2)$ i wycofania zgody $(n=2)$. Najczęstszymi objawami niepożądanymi były neutropenia $(47 \%)$, nudności (41\%), biegunka (37\%), gorączka (31\%), bóle głowy (31\%) i infekcje dróg oddechowych (29\%). Spośród 34 chorych, u których oceniano skuteczność leczenia, ORR wynosit 88\%, a 11 (32\%) chorych uzyskało CR. Obecnie jest prowadzone badanie 3. fazy w celu porównania ABT-199 z rytuksymabem do BEN $Z$ rytuksymabem u chorych wcześniej leczonych $z$ powodu CLL. Zaawansowane są również badania 1. fazy dotyczące skojarzonego leczenia ABT199 z rytuksymabem i BEN oraz obinutuzumabem u chorych na nawrotową i oporną CLL $[50,51]$.

\section{Przeciwciała monoklonalne}

Poza przeciwciałami anty-CD20 aktywność terapeutyczną w CLL wykazują również przeciwciała anty-CD37 i anty-CD19 [52]. Ich potencjalna przewaga nad przeciwciałami anty-CD20 może wynikać $z$ większej gęstości antygenów CD37 i CD19 niż CD20 na komórkach CLL. Otlertuzumab (TRU-016) jest nowym fragmentem humanizowanego przeciwciała anty-CD37 wytwarzanym za pomoca technologii ADAPTIR ${ }^{\text {тм }}$ Modular Protein Technology. Cechuje się on dużą aktywnością przeciwbiałaczkową w badaniach przedklinicznych i klinicznych [53, 54].

Przeciwciało BI 836826 (MAb 37.1) jest chimeryczną immunoglobuliną IgG1 anty-CD37 ze modyfikowanym fragmentem Fc i znaczną aktywnością przeciwbiałaczkową w mechanizmie cytotoksyczności komórkowej zależnej od przeciwciał (ADCC, andibody-dependent cellular cytotoxicity). $\mathrm{W}$ badaniach in vitro wykazywało ono większą aktywność cytolityczną przeciw komórkom CLL niż rytuksmab i alemtuzumab [55]. Obecnie jest 1. fazie badań u chorych na CLL (NCT01296932).

MOR208 (XmAb5574) jest przeciwciałem anty-CD19 również badanym w CLL. W badaniach przedklinicznych MOR208 wykazywał aktywność przeciwbiałaczkową w mechanizmie bezpośredniej toksyczności ADCC i zależnej od przeciwciał fagocytozy komórek CLL [56]. W badaniu 1. fazy wykazywał działanie przeciwbiałaczkowe i akceptowalną toksyczność u chorych na oporną i nawrotową CLL [57, 58]. Przedstawiano również zachęcające wstępne wyniki badań 2 . fazy u chorych na CLL i inne chłoniaki B-komórkowe (NCT02005289) [59].

\section{Przeszczepianie krwiotwórczych}

komórek macierzystych i immunoterapia T-komórkowa

W 2007 roku grupa robocza EBMT (European Society for Blood and Marrow Transplantation) ustaliła wskazania do wykonywania przeszczepień allogenicznych krwiotwórczych komórek macierzystych (allo-HSCT, allogeneic hematopoietic stem cells transplantation) $\mathrm{u}$ chorych na CLL [60]. Według tych zaleceń allo-HSCT powinno być rozważane u wcześniej leczonych chorych $z$ niekorzystnym rokowaniem, u których wstąpiła progresja choroby przed upływem 12 miesięcy od terapii I linii lub do 24 miesięcy od leczenia analogami puryn. Najczęstszym wskazaniem do allo-HSCT były dotychczas oporność na fludarabinę, del17p lub mutacje TP53 u chorych wymagających leczenia. Wskazania te wciąż wydają się aktualne mimo istotnego postępu $\mathrm{w}$ terapii związanego $\mathrm{z}$ zastosowaniem inhibitorów BCR i BCL2.

W ostatnich latach wprowadzono metodę kondycjonowania o zredukowanej intensywności (RIC, reduced-intensity conditioning) przed allo-HSCT, co znacznie zwiększyło bezpieczeństwo i przydatność tej metody również u starszych chorych na CLL. W badaniach przedstawionych przez Sorrora i wsp. [61] 5-letnie OS chorych bez znacznej limfodenopatii $(<5 \mathrm{~cm})$ i bez wspólistniejących chorób wynosiło $78 \%$ w porównaniu $z 27 \%$ u chorych ze znaczną limfadenopatią i wspólistniejącymi chorobami. Następnie autorzy przedstawili wyniki analizy wpływu aberracji cytogenetycznych i wcześniejszego leczenia alemtuzumabem $u$ chorych $z$ CLL wysokiego ryzyka poddawanych procedurze allo-HSCT poprzedzonej RIC (RIC-allo-HSCT) [62]. Do analizy włączono 136 chorych (mediana wieku 56 lat) po wcześniejszych wielu liniach chemioterapii (mediana 4), z których $12 \%$ przebyło kondycjonowanie za pomocą napromieniania całego ciała (TBI, total body irradiation) w dawce 2 Gy i $88 \%$ z wykorzy- 
staniem TBI w dawce 2 Gy i fludarabiny w dawce $90 \mathrm{mg} / \mathrm{m}^{2}$. W wyniku leczenia uzyskano $55 \%$ CR i $15 \%$ PR, a szacowane 5-letnie odsetki wynosily odpowiednio $32 \%$ dla NRM (non-relapse mortality), $36 \%$ dla progresji i/lub nawrotów choroby, $32 \%$ dla PFS i $41 \%$ dla OS. Spośród 138 analizowanych chorych 58 żyje, w tym 45 chorych jest w CR, $5 \mathrm{w}$ PR, $5 \mathrm{w}$ SD i $3 \mathrm{w}$ okresie progresji lub nawrotu choroby. Czynnikami wpływającymi na wzrost odsetka nawrotów po RIC-allo-HSCT były zastosowanie alemtuzumabu w ciągu 12 miesięcy przed allo-HSCT (53\% v. 31\%; $\mathrm{p}=0,007)$ i rozmiary węzłów chłonnych wynoszące co najmniej $5 \mathrm{~cm}$ (59\% v. $28 \%$; $\mathrm{p}=0,003)$. Oba czynniki miały również graniczny wpływ na PFS (odpowiednio: współczynniki ryzyka [HR, hazard ratio] $1,55, \mathrm{p}=0,09$ oraz 1,64 , $\mathrm{p}=0,06)$. Badacze podkreślają, że w analizie wielowariantowej czynnikami takimi nie były między innymi rodzaj dawcy, aberracje cytogenetyczne czy stan aktywności choroby przed allo-HSCT. Pacjenci obciążeni najwyższym ryzykiem nawrotu choroby to chorzy otrzymujący alemtuzumab w ciągu 3 miesięcy poprzedzających RIC-allo-HSCT.

W badaniu przeprowadzonym przez Michallet i wsp. [63] w kondycjonowaniu stosowano rytuksymab w dawce $375 \mathrm{mg} / \mathrm{m}^{2} \mathrm{w}$ dniu -5 . oraz fludarabinę $\mathrm{w}$ dawce $30 \mathrm{mg} / \mathrm{m}^{2} \mathrm{w}$ dniach od -4 . do -2 . i TBI w dawce 2 Gy w dniu 0. przed RIC-allo-HSCT u 40 chorych $z$ odpowiedzią na leczenie ratunkowe lub auto-HSCT. U 39 spośród 40 (98\%) chorych uzyskano rekonstytucję hematopoezy, w tym $79 \%$ uzyskało chimeryzm dawcy w 90 . dniu. Po medianie obserwacji wynoszącej 28 miesięcy mediany OS nie osiągnięto (szacunkowy odsetek po 5 latach wyniósł 55\%), mediana przeżycia wolnego od zdarzeń (EFS, event-free survival) osiągnęła 30 miesięcy (szacunkowy odsetek po 5 latach wyniósł 46\%), skumulowane ryzyko nawrotu po roku i 3 latach wyniosło odpowiednio $17 \%$ i $22 \%$, skumulowane odsetki TRM (transplant-related mortality) po roku i 3 latach wyniosły $10 \%$ i 27\%, a odsetek poważnych infekcji osiągnął 56\%. Autorzy badania podkreślili korzystny wpływ dodania rytuksymabu na zmniejszenie częstości nawrotów choroby zasadniczej i ostrej postaci choroby przeszczep przeciw gospodarzowi (GvHD, graft versus host disease) w stopniu przekraczającym 1 . $(\mathrm{p}=0,02)$.

Zenz i wsp. [64] przedstawili wyniki stosowania RIC-allo-HSCT u 90 chorych na CLL wysokiego ryzyka cytogenetycznego (obecność del17p lub/i mutacji TP53). Uzyskane odsetki 4-letniego EFS wynosily $46 \%$ w przypadku obecności mutacji TP53 (38\% z towarzyszącą del17p i $44 \%$ bez towarzyszącej del17p) oraz $38 \%$ bez mutacji TP53. Odsetki 4-letniego OS wynosiły 56\% w przypadku mutacji TP53 (50\% z towarzyszącą del17p i $56 \%$ bez towarzyszącej del17p) oraz $66 \%$ bez mutacji TP53; w wielowariantowej analizie Coxa mutacje TP53 nie wpływały na EFS. Autorzy konkludują, że RIC-allo-HSCT umożliwia uzyskanie długotrwałego EFS u około $40 \%$ chorych na CLL przebiegającą $z$ mutacjami TP53, niezależnie od towarzyszącej del17p oraz że procedura ta może przełamać oporność komórek białaczkowych wynikającą $z$ tej aberracji. Wprowadzenie nowych leków dla chorych na CLL najprawdopodobniej zmieni obecne wskazania dla allo-HSCT. Jednak obecnie nie ma randomizowanych badań służących porównaniu zastosowania nowych terapii $z$ allo-HSCT, a oporność na analogi puryn i del17p lub/i mutacje TP53 nadal pozostają najważniejszymi wskazaniami do allo-HSCT.

Immunoterapia limfocytami T CAR dla CD19 z genetycznie modyfikowaną ekspresją receptora dla CD19 stanowi obiecującą metodę leczenia u źle rokujących chorych na CLL. Pionierskie badania przeprowadzono na Uniwersytecie w Pensylwanii. Odpowiedź na leczenie uzyskano u 6 spośród 9 chorych na oporną CLL, w tym u 4 uzyskano CR [65, 66]. U wszystkich chorych wystąpił zespół cytokinowy $z$ gorączką, nudnościami, hipotonią i hipoksją; ponadto opisywano występowanie zespołu aktywacji makrofagów. Ze względu na skomplikowaną technologię i objawy niepożądane stosowanie limfocytów T CAR w CLL jest wciąż metodą eksperymentalną. Uzyskane wyniki są bardzo obiecujące i wskazują na celowość prowadzenia dalszych badań w tej dziedzinie [67]. Większość odpowiedzi miała długotrwały charakter i była związana $z$ ekspansją i długotrwałym przeżyciem limfocytów T CAR; odpowiedź uzyskano u $9(35 \%)$ chorych, w tym CR u $5(22 \%)$ i PR u 4 (17\%).

\section{Źródla finansowania}

Praca finansowana $z$ grantu Uniwersytetu Medycznego w Łodzi No 503/1-093-01/503-1.

\section{Piśmiennictwo}

1. Dighiero G., Maloum K., Desablens B. i wsp. Chlorambucil in indolent chronic lymphocytic leukemia. N. Engl. J. Med. 1998; 338: 1506-1514.

2. Schweighofer C.D., Cymbalista F., Müller C. i wsp. Early versus deferred treatment with combined fludarabine, cyclophosphamide and rituximab (FCR) improves event-free survival in patients with high-risk Binet stage A chronic lymphocytic leukemia - first results of a randomized German-French Cooperative Phase III Trial. Blood 2013; 122: abstrakt 2352. 
3. Knauf W.U., Lissitchkov T., Aldaoud A. i wsp. Bendamustine induces higher remission rates, prolongs progression free survival as well as time to next treatment, and improves overall survival for patients in complete remission without compromising quality of life when compared to chlorambucil in first line treatment of chronic lymphocytic leukemia. Blood 2010; 116: abstrakt 2449.

4. Knauf W.U., Lissichkov T., Aldaoud A. i wsp. Phase III randomized study of bendamustine compared with chlorambucil in previously untreated patients with chronic lymphocytic leukemia. J. Clin. Oncol. 2009; 27: 4378-4384.

5. Hallek M., Fingerle-Rowson G., Fink A.M. i wsp, First-line treatment with fludarabine $(\mathrm{F})$, cyclophosphamide $(\mathrm{C})$, and rituximab (R) (FCR) improves overall survival (OS) in previously untreated patients (pts) with advanced chronic lymphocytic leukemia (CLL): results of a randomized phase III trial on behalf of an International Group of Investigators and the German CLL Study Group. Blood 2009; 114: abstrakt 535.

6. Hallek M., Fischer K., Fingerle-Rowson G. i wsp. Addition of rituximab to fludarabine and cyclophosphamide in patients with chronic lymphocytic leukaemia: a randomised, open-label, phase 3 trial. Lancet 2010; 376: 1164-1174.

7. Fischer K., Bahlo J., Fink A.M. i wsp. Extended follow up of the CLL8 protocol, a randomized phase-III trial of the German CLL Study Group (GCLLSG) comparing fludarabine and cyclophosphamide (FC) to $\mathrm{FC}$ plus rituximab (FCR) for previously untreated patients with chronic lymphocytic leukemia (CLL): results on survival, progression-free survival, delayed neutropenias and secondary malignancies confirm superiority of the FCR regimen. Blood 2012; 120: abstrakt 435.

8. Eichhorst B., Fink A.M., Busch R. i wsp. Chemoimmunotherapy with fludarabine $(\mathrm{F})$, cyclophosphamide $(\mathrm{C})$, and rituximab $(\mathrm{R})$ (FCR) versus bendamustine and rituximab (BR) in previously untreated and physically fit patients (pts) with advanced chronic lymphocytic leukemia (CLL): results of a planned interim analysis of the CLL10 Trial, An international, randomized study of the German CLL Study Group (GCLLSG) Blood 2013; 122: abstrakt 526.

9. Eichhorst B., Fink A.M., Busch R. i wsp. Frontline chemoimmunotherapy with fludarabine $(\mathrm{F})$, cyclophosphamide $(\mathrm{C})$, and rituximab (R) (FCR) shows superior efficacy in comparison to bendamustine (B) and rituximab (BR) in previously untreated and physically fit patients (pts) with advanced chronic lymphocytic leukemia (CLL): Final analysis of an international, randomized study of the German CLL Study Group (GCLLSG) (CLL10 Study). Blood 2014; 124: abstrakt 9.

10. Remi L., Leprêtre S., Christine A. i wsp. CLL2007FMP, a phase III randomized multicentric trial of the French Cooperative Group On CLL and WM (FCGCLL/MW) and the „Groupe Ouest-Est D'etudes Des Leucémies Aigües Et Autres Maladies Du Sang” (GOELAMS): Immunochemotherapy with fludarabine (F), cyclophosphamide $(\mathrm{C})$, and rituximab $(\mathrm{R})(\mathrm{FCR})$ yields a significantly better response than fludarabine $(\mathrm{F})$, cyclophosphamide $(\mathrm{C})$ and MabCampath (Cam) (FCCam) in previously untreated b-chronic lymphocytic leukemia patients as evaluated by a sensitive 6 color flow cytometry MRD. Blood 2010; 116: abstrakt 698.

11. Robak T., Blonski J.Z., Jamroziak K. i wsp A Randomized, multicenter study (PALG CLL4/ML 21283) of maintenance treatment with rituximab versus observation after induction treatment with rituximab, cladribine, and cyclophosphamide (RCC) regimen in patients with progressive chronic lymphocytic leukemia: Interim analysis. Blood 2013; 122: abstrakt 1640.
12. Goede V., Fischer K., Busch R. i wsp. Head-to-head comparison of obinutuzumab (ga101) plus chlorambucil (clb) versus rituximab plus clb in patients with chronic lymphocytic leukemia (cll) and co-existing medical conditions (comorbidities): final stage 2 results of the CLL11 trial. Blood 2013; 122: abstrakt 6 .

13. Goede V., Fischer K., Busch R. i wsp. Obinutuzumab plus chlorambucil in patients with CLL and coexisting conditions. N. Engl. J. Med. 2014; 370: 1101-1110.

14. Hillmen P., Robak T., Janssens A. i wsp. Ofatumumab + chlorambucil versus chlorambucil alone in patients with untreated chronic lymphocytic leukemia (CLL): results of the phase III study complement 1 (OMB110911). Blood 2013; 122: abstrakt 528.

15. Leblond V., Laribi K., Ilhan O. i wsp. Rituximab in combination with bendamustine or chlorambucil for treating patients with chronic lymphocytic leukemia: interim results of a phase IIIb study (MaBLe). Blood 2012; 120: abstrakt 2744.

16. Eichhorst B., Dreyling M., Robak T. i wsp.; ESMO Guidelines Working Group. Chronic lymphocytic leukemia: ESMO Clinical Practice Guidelines for diagnosis, treatment and follow-up. Ann. Oncol. 2011; 22 (supl. 6): vi50-vi54.

17. Cramer P., Isfort S., Bahlo J. i wsp. The use of chemoimmunotherapy improves the outcome of patients with chronic lymphocytic leukaemia (CLL) - a metaanalysis of five trials of the German CLL Study Group (GCLLSG). Blood 2012; 120: abstrakt 3936.

18. Robak T. Maintenance in CLL. Blood 2013; 122: 3854-3855.

19. Egle A., Weiss L., Melchardt T. i wsp. Final analysis of induction treatment with fludarabine, cyclophosphamide plus rituximab (FCR) followed by fludarabine plus rituximab (FR) and remission maintenance therapy with rituximab in previously untreated B-chronic lymphocytic leukemia (B-CLL): the Chairos AGMT CLL4/Roche ML18434 study. Blood 2010; 116: abstrakt 1380.

20. Garcia-Marco J.A., Lopez-Jimenez J., Ferrer S. i wsp. Rituximab maintenance treatment after combined fludarabine, cyclophosphamide and rituximab in previously untreated patients with progressive B-cell chronic lymphocytic leukemia (CLL): Interim analysis of an ongoing phase II multicenter trial on behalf of the Spanish CLL Study Group (GELLC). Blood 2010; 116: abstrakt 2448.

21. Bosch F., Villamor N., Abrisqueta P. i wsp. Rituximab Maintenance In Patients with Chronic Lymphocytic Leukemia (CLL) sustains the response obtained after first-line treatment with rituximab plus fludarabine, cyclophosphamide, and mitoxantrone (R-FCM). Blood 2010; 116: abstrakt 1382.

22. Abrisqueta P., Villamor N., Terol M.J. i wsp. Rituximab maintenance after first-line therapy with rituximab, fludarabine, cyclophosphamide, and mitoxantrone (R-FCM) for chronic lymphocytic leukemia. Blood 2013; 122: 3951-3959.

23. Shanafelt T., Tun H., Hanson C. i wsp. Lendalidomide consolidation after first-line chemoimmunotherapy for patients with previously untreated CLL. Blood 2010; 116: abstrakt 1379.

24. van Oers M., Kuliczkowski K., Smolej L. i wsp. Ofatumumab (OFA) maintenance prolongs PFS in relapsed CLL: interim analysis results of the phase III PROLONG study. Blood 2014; 124: abstrakt 21.

25. Chang J.E., Zhang C., Kim K.M. i wsp. Bendamustine + rituximab (BR) chemoimmunotherapy and maintenance lenalidomide in relapsed/refractory ( $r / r)$ chronic lymphocytic leukemia (CLL) and small lymphocytic lymphoma (SLL): a Wisconsin Oncology Network (WON) Study. Blood 2012; 120: abstrakt 3647.

26. Thompson P.A., Keating M.J., Hinojosa C. i wsp. Lenalidomide and rituximab in combination as initial treatment of chronic lymphocytic leukemia: initial results of a Phase II Study. Blood 2014; 124: abstrakt 1988. 
27. Varghese A.M., Cohen D., Pocock C.F.E. i wsp. NCRN CLL207 study of alemtuzumab consolidation in CLL: final response assessment and early follow-up (on behalf of the NCRI CLL Trials Sub-Group). Blood 2010; 116: abstrakt 60.

28. Robak T., Robak P. BCR signaling in chronic lymphocytic leukemia and related inhibitors currently in clinical studies. Int. Rev. Immunol. 2013; 32: 358-376.

29. Byrd J.C., Furman R.R., Coutre S.E. i wsp. Targeting BTK with ibrutinib in relapsed chronic lymphocytic leukemia. N. Engl. J. Med. 2013; 369: 32-42.

30. Byrd J.C., Furman R.R., Coutre S. i wsp.The Bruton's tyrosine kinase (BTK) inhibitor ibrutinib (PCI-32765) promotes high response rate, durable remissions, and is tolerable in treatment naïve (TN) and relapsed or refractory (RR) chronic lymphocytic leukemia (CLL) or small lymphocytic lymphoma (SLL) patients including patients with high-risk (HR) disease: new and updated results of 116 patients in a phase Ib/II Study. Blood 2012; 120: abstrakt 189.

31. Burger J.A., Keating M.J., Wierda W.G. i wsp. The Btk inhibitor ibrutinib (PCI-32765) in combination with rituximab is well tolerated and displays profound activity in high-risk chronic lymphocytic leukemia (CLL) patients. Blood 2012; 120: abstrakt 187.

32. Byrd J.C., Brown J.R., O'Brien S. i wsp. RESONATE Investigators. Ibrutinib versus ofatumumab in previously treated chronic lymphoid leukemia. N. Engl. J. Med. 2014; 371: 213-223.

33. O'Brien S., Jones J.A., Coutre S. i wsp. Efficacy and safety of ibrutinib in patients with relapsed or refractory chronic lymphocytic leukemia or small lymphocytic leukemia with $17 \mathrm{p}$ deletion: results from the phase II RESONATE ${ }^{\mathrm{TM}}-17$ trial. Blood 2014; 124 : abstrakt 327.

34. Brown J.R., Hillmen P., O'Brien S. i wsp. Updated efficacy including genetic and clinical subgroup analysis and overall safety in the phase 3 RESONATE $^{\mathrm{rm}}$ trial of ibrutinib versus ofatumumab in previously treated chronic lymphocytic leukemia/small lymphocytic lymphoma. Blood 2014; 124: abstrakt 3331.

35. Farooqui M., Aue G., Valdez J. i wsp. Single agent ibrutinib (PCI-32765) achieves equally good and durable responses in chronic lymphocytic leukemia (CLL) patients with and without deletion 17p. Blood 2013; 122: abstrakt 673.

36. Burger J.A., Keating M.J., Wierda W.G. i wsp. Ibrutinib in combination with rituximab $(\mathrm{iR})$ is well tolerated and induces a high rate of durable remissions in patients with high-risk chronic lymphocytic leukemia (CLL): new, updated results of a phase ii trial in 40 patients. Blood 2013; 122: abstrakt 675.

37. Brown J.R., Barrientos J.C., Barr P.M. i wsp. Ibrutinib in combination with bendamustine and rituximab is active and tolerable in patients with relapsed/refractory CLL/SLL: final results of a phase $1 \mathrm{~b}$ study Blood 2013; 122: abstrakt 525.

38. Thompson P.A., Wierda W.G., Ferrajoli A. i wsp. Complex karyotype is a stronger predictor than del(17p) for inferior outcome in relapsed or refractory CLL patients treated with ibrutinib-based regimens. Blood 2014; 124: abstrakt 22.

39. Furman R.R., Sharman J.P., Coutre S.E. i wsp. A phase 3, randomized, double-blind, placebo-controlled study evaluating the efficacy and safety of idelalisib and rituximab for previously treated patients with chronic lymphocytic leukemia (CLL). Blood 2013; 122: abstrakt LBA-6.

40. Sharman J.P., Coutre S.E., Furman R.R. i wsp. Second interim analysis of a phase 3 study of idelalisib $\left(\right.$ ZYDELIG $\left.^{\circledR}\right)$ plus rituximab for relapsed chronic lymphocytic leukemia: efficacy analysis in patient subpopulations with del(17p) and other adverse prognostic factors. Blood 2014; 124: abstrakt 330
41. Furman R.R., Sharman J.P., Coutre S.E. i wsp. Idelalisib and rituximab in relapsed chronic lymphocytic leukemia. N. Engl. J. Med. 2014; 370: 997-1007.

42. Barrientos J.C., Wagner-Johnston N.D., De Vos S. i wsp. Chemoimmunotherapy combination of idelalisib with bendamustine/ /rituximab or chlorambucil/rituximab in patients with relapsed/ /refractory CLL demonstrates efficacy and tolerability. Blood 2013; 122: abstrakt 4176.

43. Furman R.R., De Vos S., Leonard J.P. i wsp. A phase 1 study of the selective pi3k inhibitor idelalisib (GS-1101) in combination with therapeutic anti-CD20 antibodies (rituximab or ofatumumab) in patients with relapsed or refractory chronic lymphocytic leukemia. Blood 2013; 122: abstrakt 4180

44. Fegan C., Bagshawe J., Salles G. i wsp. The Bruton's tyrosine kinase (BTK) inhibitor ONO-4059: promising single agent activity and well tolerated in patients with high risk chronic lymphocytic leukaemia (CLL). Blood 2014; 124: abstrakt 3328.

45. O’Brien S., Patel M., Kahl B.S. i wsp. Duvelisib (IPI-145), a PI3K- $\delta, \gamma$ inhibitor, is clinically active in patients with relapsed/ /refractory chronic lymphocytic leukemia. Blood 2014; 124: abstrakt 3334

46. Porcu P., Flinn I., Kahl B.S. i wsp. Clinical activity of duvelisib (IPI-145), a phosphoinositide-3-kinase- $\delta, \gamma$ inhibitor, in patients previously treated with ibrutinib. Blood 2014; 124: abstrakt 3335 .

47. Souers A.J., Leverson J.D., Boghaert E.R. i wsp. ABT-199, a potent and selective BCL-2 inhibitor, achieves antitumor activity while sparing platelets. Nat. Med. 2013; 19: 202-208.

48. Seymour J.F., Davids M.S., Pagel J.M. i wsp. Bcl-2 Inhibitor ABT199 (GDC-0199) monotherapy shows anti-tumor activity including complete remissions in high-risk relapsed/refractory $(\mathrm{R} / \mathrm{R})$ chronic lymphocytic leukemia (CLL) and small lymphocytic lymphoma (SLL). Blood 2013; 122: abstrakt 872 .

49. Roberts A.W., Ma S., Brander D.M. i wsp. Determination of recommended phase 2 dose of ABT-199 (GDC-0199) combined with rituximab $(\mathrm{R})$ in patients with relapsed/refractory $(\mathrm{R} / \mathrm{R})$ chronic lymphocytic leukemia (CLL). Blood 2014; 124: abstrakt 325.

50. Salles G., Boyd T.E., Morschhauser F. i wsp. Preliminary results of a phase 1b study (GO28440) combining GDC-0199 (ABT-199) with bendamustine/rituximab in patients with relapsed/refractory or previously untreated chronic lymphocytic leukemia. Blood 2014; 124: abstrakt 3337.

51. Flinn I., Brunvand M., Dyer M.J.S. i wsp. Preliminary results of a phase 1b study (GP28331) combining GDC-0199 (ABT-199) and obinutuzumab in patients with relapsed/refractory or previously untreated chronic lymphocytic leukemia. Blood 2014; 124: abstrakt 4687.

52. Robak T., Robak P. Anti-CD37 antibodies for chronic lymphocytic leukemia. Exp. Opin. Biol. Ther. 2014; 14: 651-661.

53. Byrd J.C., Pagel J.M., Awan F.T. i wsp. A phase 1 study evaluating the safety and tolerability of otlertuzumab (TRU-016), an anti-CD37 mono-specific ADAPTIRTM therapeutic protein in chronic lymphocytic leukemia. Blood 2014; 123: 1302-1308.

54. Robak T., Hellman A., Kloczko J. i wsp. Phase 2 study of otlertuzumab (TRU-016), an anti-CD37 ADAPTIRTM protein, in combination with bendamustine vs bendamustine alone in patients with relapsed chronic lymphocytic leukemia (CLL). Blood 2013; 122: abstrakt 2860.

55. Heider K.H., Kiefer K., Zenz T. A novel Fc-engineered monoclonal antibody to CD37 with enhanced ADCC and high proapoptotic activity for treatment of B-cell malignancies. Blood 2011; 118: 4159-4168. 
56. Awan F.T., Lapalombella R., Trotta R. i wsp. CD19 targeting of chronic lymphocytic leukemia with a novel Fc-domain-engineered monoclonal antibody. Blood 2010; 115: 1204-1213.

57. Woyach J.A., Avan F., Flinn I.W. i wsp. final results of a phase $\mathrm{i}$ study of the Fc engineered CD19 antibody $\mathrm{XmAb}^{\circledR} 5574$ (MOR00208) in patients with relapsed or refractory chronic lymphocytic leukemia (CLL) or small lymphocytic lymphoma (SLL). Blood 2012; 120: abstrakt 2894.

58. Woyach J.A., Awan F., Flinn I.W. i wsp. A phase 1 trial of the Fc-engineered CD19 antibody XmAb5574 (MOR00208) demonstrates safety and preliminary efficacy in relapsed CLL. Blood 2014; 124: 3553-3560.

59. Blum K.A., Maddocks K., Nagy Z. i wsp. A Phase IIa, open-label, multicenter study of single-agent MOR00208, an Fc-optimized anti-CD19 antibody, in patients with relapsed or refractory B-cell non-Hodgkin's lymphoma. Blood 2014; 124: abstrakt 3089.

60. Dreger P., Corradini P., Kimby E. i wsp. Indications for allogeneic stem cell transplantation in chronic lymphocytic leukemia: the EBMT transplant consensus. Leukemia 2007; 21: 12-17.

61. Sorror M.L., Storer B.E., Sandmaier B.M. i wsp. Five-year follow-up of patients with advanced chronic lymphocytic leukemia treated with allogeneic hematopoietic cell transplantation after non-myeloablative conditioning. J. Clin. Oncol. 2008; 26: 4912-4920.

62. Sorror M.L., Storer B., Sandmaier B.M. i wsp. Impacts of cytogenetic abnormalities and prior alemtuzumab on outcomes of patients (pts) with high-risk chronic lymphocytic leukemia (CLL) given nonmyeloablative allogeneic hematopoietic cell transplantation (HCT). Blood 2010; 116: abstrakt 2364.

63. Michallet M., Sobh M., Morisset S. i wsp. Rituximab in allogeneic hematopoietic stem cell transplantation for advanced chronic lymphocytic leukemia with fludarabine + total body irradiation conditioning: results of a phase II prospective multicenter study (ITAC 02-02). Blood 2010; 116: abstrakt 3520.

64. Zenz T., Dreger P., Dietrich S. i wsp. allogeneic stem cell transplantation can overcome the adverse prognostic impact of TP53 mutation in chronic lymphocytic leukemia (CLL): Results from the GCLLSG CLL3x trial. Blood 2010; 116: abstrakt 2357.

65. Porter D.L., Levine B.L., Kalos M., Bagg A., June C.H. Chimeric antigen receptor-modified T cells in chronic lymphoid leukemia. N. Engl. J. Med. 2011; 365: 725-733.

66. Porter D.L., Frey N.V., Loren A.W. i wsp. A phase II, dose-optimization trial of autologous $\mathrm{T}$ cells genetically engineered to express anti-CD19 chimeric antigen receptor (CART-19) in patients with relapsed or refractory (R/R) CD19+ chronic lymphocytic leukemia (CLL). J. Clin. Oncol. 2013; 31 (supl.): abstrakt TPS7132.

67. Porter D.L., Frey N.V., Melenhorst J.J. i wsp. Randomized, phase II dose optimization study of chimeric antigen receptor modified t cells directed against CD19 (CTL019) in patients with relapsed, refractory CLL. Blood 2014; 124: abstrakt 1982. 